\title{
ALTERAÇÃO DO MÉTODO DE GRAVAÇÃO DE EIXOS FERROVIÁRIOS - UM ESTUDO DE CASO
}

\section{Marcus Vinicius Souza Dias ${ }^{1}$ Giorgio Eugênio Oscare Giacaglia²}

Resumo: Com a competitividade cada dia mais acirrada no mercado, empresas se desenvolvem e aprimoram suas estratégias e tecnologias. Com este cenário é imprescindível o olhar crítico dos responsáveis pelo processo, na busca da melhoria contínua dentro do processo de manufatura, buscando aprimorar as atividades através de novos métodos e ferramentas. Sendo assim, este artigo busca apresentar, por meio de um estudo de caso, dentro de uma empresa metalúrgica do ramo ferroviário, de médio porte, no setor de usinagem de eixos ferroviários, como a alteração do método de gravação em eixos ferroviários trouxe ao processo: economia $(R \$)$, maior rastreabilidade (controle do produto) e melhoria ergonômica; itens de extrema importância em um cenário de alta competitividade.

Palavras-chave: Eixos ferroviários; Método de gravação; Economia; Rastreabilidade; Ergonomia.

1 Mestrado em Engenharia Mecânica I Universidade de Taubaté (UNITAU), Brasil. E-mail: marvinidias28@gmail.com.

${ }^{2}$ Orientador / Universidade de Taubaté (UNITAU), Brasil. E-mail: giorgio.giacaglia@unitai.com.br. 